\section{IOWA AND AFTER}

After months of manoeuvre and preliminary debate, on 3 January the lowa caucuses mark the start of the formal process by which the US political parties will choose their presidential candidates. A host of issues are on the table, and science is not high on the list. Nevertheless some scientific issues are cropping up out on the campaign trail.

Stem cells, although still an issue, seem to have taken a back seat, even though the new president would be in a position to repeal President George W. Bush's 2001 restrictions on federal funding for research on embryonic stem-cell lines. Climate and energy receive a lot of attention, with candidates happy to talk of emissions reductions that would bite far after their terms have ended, and with some who have previously opposed corn-ethanol subsidies changing their minds when looking for votes among the lowa cornfields. Spending on the physical sciences, other than energy, comes up rarely - although Senator Barack Obama's proposal to take funds from NASA's planned shuttle replacement has ruffled some feathers.

Nature's Eric Hand takes a look at the leading candidates' stances on some science-related issues.

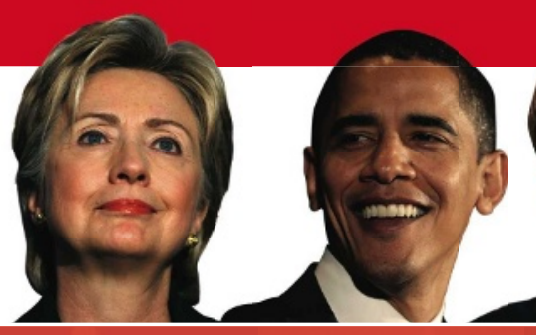

HILLARY

CLINTON (DEMOCRAT)

SENATOR FROM

NEW YORK, FORMER FIRST LADY

BARACK OBAMA

(DEMOCRAT)

SENATOR FROM

ILLINOIS

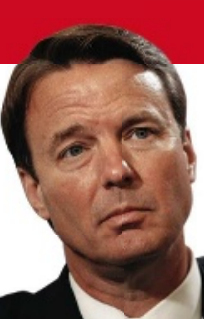

JOHN EDWARDS

(DEMOCRAT) FORMER SENATOR FROM NORTH CAROLINA
Calls for reducing from 1990 levels by 2050 via a capand-trade system. Does not support a carbon tax but argues for standards on efficiency, mileage, and renewable energy to meet that goal. Says she is "agnostic" about nuclear power. emissions by $80 \%$
Calls for reducing emissions by $80 \%$ from 1990 levels by 2050 via a capand-trade system. Wants to invest $\$ 150$ billion over 10 years in alternative energy sources. Supports coal liquefaction, but only if it emits $20 \%$ less carbon than conventional fuels.
Calls for reducing emissions by $80 \%$ from 1990 levels by 2050 via a cap-andtrade system. Wants to push for a climate change treaty that has binding elements for all countries, including those in the developing world. Opposes nuclear power - says it's too costly to build new plants and too unsafe to dispose of waste.

Supports federal funding for embryonic stem-cell research. Proposed increasing National Institutes of Health budget by $50 \%$ over five years, and doubling it over ten years.

"My 5th grade teacher "We're not going to Mrs Kraus came into our classroom and said we had to study math and science because the President said so. I was convinced that President Eisenhower had called up Mrs

Kraus and told her

'You tell those children - and particularly that Hillary, who doesn't really like math - that her country needs her."'

\section{Supports federal} funding for embryonic stem-cell research.

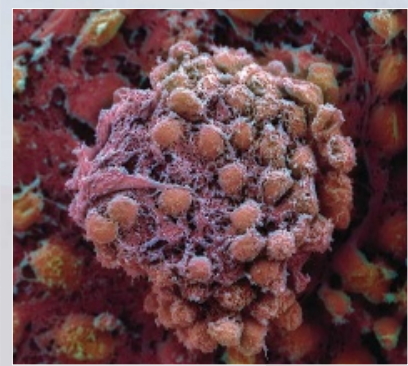

Would delay NASA's Constellation programme to build new rockets and crew vehicles for five years, instead putting that money toward an $\$ 18$ billion education plan.
Supports human exploration of space, and says other countries should also be involved.

\section{"Colleges are the places where we ensure that America is competitive. Yet we've taken away funding for the $\mathrm{NIH}$ and our research universities. That's just a mistake."} and scientists to continue space exploration if we don't have kids who are

able to read, write and compute."
Supports federal funding for embryonic stem-cell research. funding for embryonic stem-cell research. Proposed a state-funded embryonic stemcell research centre at the University of New Mexico in Albuquerque.
Sees space as a

"bona fide area of economic growth and opportunity". Pushed for a sales tax to support the building of a spaceport in $\mathrm{New}$ Mexico.
"I myself have been told that I have a lot of energy. The secret is that I use renewable resources. Some days I'm solar powered. Some days I'm wind powered. And some days my critics just think I'm full of compressed air."
Calls for reducing emissions by $80 \%$ from 1990 levels by 2050 . Wants every US car sold to be equipped with flex-fuel technology, and half of all major gas stations to offer biofuels by 2017 .

Supports ethanol transitional solution for energy woes, but says it is not sustainable in the long term and pushes for cellulosic sources.

Supports federal embryonic stem-cell
Wants to make China a full partner in space exploration rather than a "frustrated new entrant" that has to catch up with the United States. from corn as a funding for research.

JOE BIDEN reserch. 


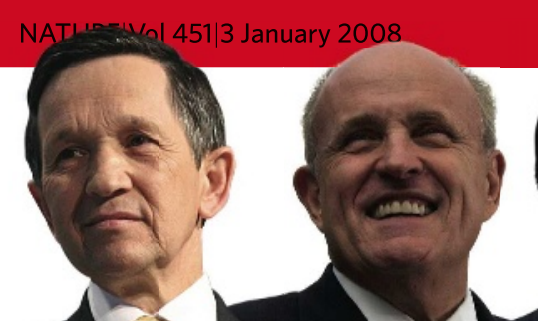

DENNIS

KUCINICH

(DEMOCRAT)

REPRESENTATIVE

FROM OHIO

\section{RUDY GIULIANI \\ (REPUBLICAN)}

FORMER MAYOR

OF NEW YORK CITY

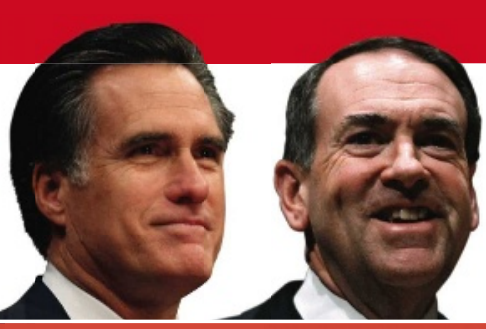

MIKE

HUCKABEE

(REPUBLICAN)

FORMER

GOVERNOR OF

ARKANSAS
GOVERNOR OF
MASSACHUSETTS

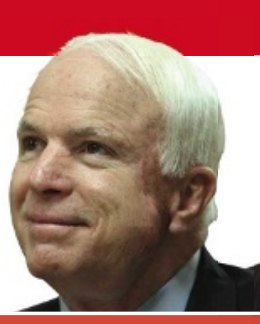

JOHN MCCAIN

(REPUBLICAN)

SENATOR FROM

ARIZONA
FRED THOMPSON RON PAUL

(REPUBLICAN)

TELEVISION ACTOR

AND FORMER

SENATOR FROM

TENNESSEE
Calls for reducing emissions by $80 \%$ from 1990

levels by 2050 potentially via a carbon tax. Proposes a Works Green Administration buildings with wind and solar power. Wants to halt all mining and logging on public land. that would retrofit
Supports federal funding for research "There are so many different things that stem-cell research can teach us." embryonic stem-cell
Wants NASA to focus "more on earthly projects" such as producing green energy. Says "eventually" be exploration. innovations will turned into space
Supports expanding nuclear power and ethanol subsidies. Does not support increasing mileage standards or mandatory caps on emissions.
Supports federal funding for embryonic stemcell research from surplus embryos from fertilization clinics: "As long as we're not creating life in order to destroy it, as long as we're not having human cloning, and we limit it to that

... there is plenty of opportunity to then use federal funds

in those situation where you have limitations."

Says he will continue to aggressively support space exploration. In response to a child's question, said he would be prepared alien attack. federal funding for to defend against an
In 2004 launched a plan to address global warming, though at the time he questioned if it was happening. Pulled out of a New England emission plan (implemented by his successor). Favours tariff protection for the corn-ethanol industry. "We should not exchange dependence on oil from other countries for dependence on sugar cane from Brazil."

Supports expanding raising mileage standards. "It's a sin against future generations for me to act as if there are no future generation that should enjoy the world as I do."

\section{Calls for a ban on} creating embryos for research purposes, but does not oppose the use of surplus embryos from in vitro fertilization clinics. Does not support the research.

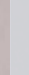

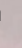
nuclear power and
Opposes federal Supports embryonic funding of embryonic stem-cell research. stem-cell research, "I believe that we and points to work need to fund this. on adult stem cells This is a tough issue instead. for those of us in the pro-life community. I would remind you that these stem cells are either going to be discarded or perpetually frozen. We need to do what we can to relieve human suffering."
Senate on globalwarming legislation Joseph Lieberman (Ind, Connecticut) to cut emissions by 1990 levels by 2050 Does not support criticized ethanol as an alternative fuel, but now supports it, citing the rising cost of oil.

ays there is no scientific consensus about the cause of global warming, but that it makes sense to take "reasonable

steps" to reduce emissions without harming the economy.

Voted against ethanol subsidies but now says he supports them.

Voted against raising mileage standards and for drilling in the Arctic National Wildlife Refuge.

Opposes stem-cell research that requires the destruction of human embryos. Says that embryonic research hasn't had a breakthrough, and cites a disputed list of 73 'breakthroughs' that use adult stem cells.
Supports the space Broadly supports programme as a way space exploration to drive investment as a trigger for in technology and technology innovation. Says he has no reason to change Bush's plan for NASA. development. "Now whether we need to send somebody to

Mars, I don't know. But I'll tell you what: If we do, I've got a few suggestions, and maybe Hillary could be on the first rocket to Mars."

\section{"If you want to} believe that you and your family came from apes, I'll accept that."

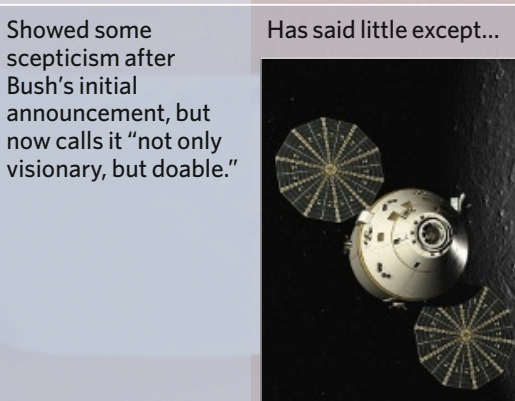

On the push for global-warming legislation: "Inaction could be disastrous."

... "[Reports of rising temperatures on other planets have] led some people, not necessarily
"More people in this country have seen UFOs than I think approve of George Bush's presidency." dangerous. So is But no one's died from nuclear power in the United States. So our commitment here is to expand it, make sure it's safe."

\section{God designed the}

Universe and created the Universe. believe he used the process of evolution to create the human body." scientists, to wonder if Mars and Jupiter, non-signatories to the Kyoto Treaty, are actually inhabited by alien SUV-driving industrialists who run their air conditioning at 60 degrees and refuse 